\title{
SISTEM PAKAR EVALUASI PSIKOLOGIS REMAJA PADA LEMBAGA INDONESIA CREATIVE CENTRE JAKARTA
}

\author{
Henny Destiana ${ }^{1)}$, Sari Suleha ${ }^{2)}$ \\ ${ }^{1)}$ Program Studi Manajemen Informatika \\ AMIK BSI BANDUNG \\ Jl. Sekolah Internasional No. 1-6 Antapani Bandung \\ henny.hnd@bsi.ac.id \\ ${ }^{2)}$ Program Studi Sistem Informasi \\ STMIK Nusa Mandiri Jakarta \\ Jl.Kramat Raya No.18 Jakarta Pusat \\ shary.bontot@gmail.com
}

\begin{abstract}
Expert System or popular name is psikotest surely already in common and become a regular activity in schools and institutions both large companies and small companies. There are various types of offers and the quality offered, but generally give the same picture as good.Psychological evaluations for students is a device used to illustrate the uniqueness of the individual's personality and their potential. Based on the understanding of the needs from the school, obtained from research on existing educational institutions that schools have needs different levels.The answer from an expert on a consultation of trustworthy and accountable and has a value of quality results, because an expert control field has been practiced based on the experience and knowledge gained. The method used in the design of this expert system application is Ranut Forward. Application of expert system is useful to help users in analyzing interest talents by way of input answers of statements that have been there on this expert system in every aspect from the input data condition statement to answer her, then get the results of the analysis of interest flair complete with analysis profession that should be focused over the interests of his talent.
\end{abstract}

\section{Key Word : Psychological Evaluation, Expert System, Interest Talents}

\section{PENDAHULUAN}

Evaluasi psikologis untuk siswa adalah sebuah perangkat yang digunakan untuk memberikan gambaran keunikkan kepribadian individu dan potensi yang dimiliknya. Berdasarkan pemahaman atas kebutuhan sekolah, dari penelitian yang didapatkan terhadap institusi pendidikan yang ada bahwa sekolah memiliki tingkat kebutuhan yang berbeda beda.

Menurut (Andayati, 2012) dalam penelitiannya :

Rothwell Miller Inventory Blank (RMIB) merupakan instrumen tes baku/formal yang dibuat oleh RothwellMiller, serta telah banyak dipakai untuk mengukur bakat dan minat seseorang. Pada dasarnya setiap orang memiliki bakat dan minat tertentu, oleh karena itu perlu suatu penganalisaan atau prediksi untuk mengetahui bakat dan minat yang ada dalam diri setiap individu. Alat tes ini banyak digunakan untuk dunia pendidikan misalnya penjurusan di SMA dan Perguruan Tinggi, serta dapat digunakan untuk dunia kerja dalam penentuan posisi jabatan seseorang (placement). Tes ini bisa juga digunakan untuk mengantisipasi kesenjangan antara keinginan orang tua dan keinginan anak dalam memilih studinya, misalnya seorang bapak mempunyai profesi menjadi dokter, dan seorang ibu mempunyai profesi seorang akuntan. Bapak menghendaki anaknya dapat meneruskan untuk menjadi dokter, dan ibu juga menghendaki ada anaknya yang dapat menjadi akuntan. Hal diatas akan menimbulkan suatu permasalahan, andaikan bapak dan ibu selaku orang tua memaksakan kehendak 
pada anaknya, dengan berbagai bujukan dan rayuan. Untuk mencari solusi dari masalah yang ada, maka orang tua akan bijak seandainya pada anaknya dilakukan tes minat bakat. Orang tua akan tahu anaknya condong ke profesi dokter ataukah sebagai akuntan, bisa jadi anaknya tidak punya bakat dan minat dikedua profesi diatas, tapi memiliki minat bakat yang lain, misalnya di dunia musik atau penyiar yang jauh dari profesi orang tuanya.

Jawaban dari seorang pakar (expert) atas sebuah konsultasi tentu dapat dipercaya dan dipertanggung jawabkan dan memiliki nilai hasil yang berkualitas, dikarenakan seorang pakar (expert) menguasai bidang yang telah ditekuninya berdasarkan pengalaman dan ilmu yang didapat

\section{Maksud dan tujuan}

Maksud dari penulisan jurnal ini adalah :

Dalam penulisan jurnal ini penulis mempunyai tujuan yang diharapkan dapat terlaksana dengan baik, adapun maksud penulisan ini adalah:

a) Penulis mempermudah psikolog dalam menganalisa kondisi psikologis minat dan bakat siswa dari jawaban yang telah diberikan, dan dapat mengarahkan siswa tersebut untuk mendapatkan apa yang sebernarnya dia ingin dapatkan.

b) Penulis mencoba memberikan hitungan analisa evaluasi psikologis minat dan bakat yang lebih pasti dari pengalaman para ahli psikolog.

Sedangkan tujuan dari penulisan ini adalah untuk membantu pengguna dalam menganalisa minat bakat dengan cara melakukan input jawaban dari pernyataan yang telah ada pada sistem pakar ini di setiap aspek

\section{Ruang lingkup}

Dalam ruang lingkup penulisan Jurnal ini, penulis membatasi perancangan sistem pakar dari kategori tes yang dianalisa yaitu tes minat dan bakat siswa untuk sekolah menengah pertama, Admin untuk mendaftarkan guru dan siswa, serta guru untuk melihat hasil test minat bakat dari siswanya. maka di dapatkan hasil analisa dari minat bakat lengkap dengan analisa profesi yang seharusnya difokuskan sesuai minat bakatnya siswa

\section{KAJIAN LITERATUR}

Menurut (Sukmoko, 2006) "Yang dimaksud bakat adalah bukan yang mengacu kepada kecakapan teknis dasar untuk suatu profesi tertentu, tetapi sebuah unsur kepribadian yang menentukan apakah seseorang menjadi mampu atau tidak mampu melakukan sesuatu dengan baik atau tidak baik".

Evaluasi psikologis atau tes intelegensi adalah salah satu cara untuk mengukur sejauh mana bakat dan kemampuan kualitas yang dimiliki seseorang. Menurut Jhonson dalam (Prasetyono, 2008) memberikan empat batasan pada kata intelegensi:

1. Yang berkaitan dengan informasi dalam arti timbal balik, jarak jauh, maupun sesuatu yang rahasia.

2. Berkaitan dengan perkenalan atau persyaratan didalam kehidupan masyarakat dan hubungannya dengan yang lain.

3. Berkaitan dengan ruh atau batin yang tidak mempunyai wadah.

4. Kemampuan untuk mengerti, keahlian, atau talenta. Tetapi, dalam hal ini ia lebih menekankan pada kemampuan atau bakat. Bakat yang dicapai setelah lahir, artinya kemampuan dan bakat-bakatnya itu akan mencapai kualitas maksimum setelah melalui proses-proses pengenalan, pengertian, dan pemahaman sebagai bentuk dari pengalaman nyata.

Sedangkan menurut Galton dalam (Prasetyo, 2008) mengemukakan bahwa "Kata intelegensi menunjukkan adanya kemampuan menyelesaikan masalah yang sudah ada sejak lahir". Dalam hal ini Galton adalah orang pertama yang berhasil menentukan hal ini dengan jelas berdesarkan penelitian-penelitian dibidang genetika.

Secara sederhana, intelegensi adalah satu faktor yang berbeda antara individu dan berasosiasi dengan tingkat kemampuan umum yang diperagakan dalam melakukan aneka ragam tugas yang berbeda dan banyak variasinya.

Pengertian dari sistem pakar menurut Martin dan Oxman dalam (Kusrini, 2006) adalah "Sistem berbasis komputer yang menggunakan pengetahuan, fakta, dan teknik penalaran dalam memecahkan masalah yang biasanya dapat dipecahkan oleh seorang pakar dalam bidang tersebut". 
Pada dasarnya sistem pakar diterapkan untuk mendukung aktivitas pemecahan masalah. Beberapa aktivitas masalah yang dimaksud antara lain : pembuatan keputusan, pemanduan pengetahuan, pembuatan desain, perancanaan, prakiraan, pengaturan, pengendalian, diagnosis, perumusan, penjelasan., pemberian nasihat, dan pelatihan. Selain itu sistem pakar juga berfungsi sebagai asisten yang pandai dari seorang pakar (Kusrini, 2006).

Menurut Heckerman dalam (Kusrini, 2006) menyatakan bahwa "Sistem pakar untuk melakukan diagnosis kesehatan telah dikembangkan sejak tahun 1970. Sistem pakar untuk melakukan diagnosis pertama dibuat oleh Bruce Buchanan dan Edward Shortliffe".

\section{METODE PENELITIAN}

Metode penelitian adalah cara ilmiah untuk mengumpulkan data dengan tujuan dan kegunaan tertentu. Metodologi yang digunakan dalam melaksanakan penelitian ini adalah SDLC (System Development Life Cycle). SDLC merupakan suatu proses yang saling berhubungan untuk membuat sebuah sistem, mendesain sebuah sistem, membangun dan menyampaikannya kepada user. Ada beberapa model yang dikembangkan berdasarkan prinsip $S D L C$ sesuai sistem yang akan diimplementasikan. Pengembangan sistem pada penelitian ini menggunakan Sedangkan untuk metode pengembangan Software menggunakan metode Waterfall.

\section{PEMBAHASAN}

\section{A. Tinjauan perusahaan}

Pertama kali didirikan pada tahun 2002 dalam bentuk perkumpulan atau LSM yang bergerak dibidang pendidikan dengan mengadakan kegiatan pemilihan raja ratu buku tingkat nasional. Kemudian mengembangkan diri sebagai bentuk cv yang menangani bidang pendidikan.

$$
\begin{aligned}
& \text { Indonesian Creative Centre (ICC) adalah } \\
& \text { lembaga penyelenggara pelatihan } \\
& \text { pengembangan SDM, evaluasi psikologis, } \\
& \text { training, dan outbond. Memberikan pelayan } \\
& \text { konsultasi untuk dunia pendidikan, keluarga, } \\
& \text { instansi maupun perusahaan. Jenis evaluasi } \\
& \text { psikoligis yang diberikan memiliki fungsi } \\
& \text { antara lain : } \\
& \text { 1. Pemetaan karakter } \\
& \text { 2. Mengetahui tingkat kecerdasanatau } \\
& \text { EQ }
\end{aligned}
$$

3. Minat dan bakat

4. Memberikan pertimbangan saran dan jurusan profesi.

\section{B. Rancangan algoritma}

Dalam penyusunannya, sistem pakar mengombinasikan kaidah-kaidah penarikan kesimpulan (inference rules) dengan basis pengetahuan tertentu yang diberikan oleh satu sama lain pakar dalam bidang tertentu. Kombinasi dari kedua hal tersebut disimpan dalam komputer, yang selanjutnya digunakan dalam proses pengambilan keputusan untuk penyelesaian masalah tertentu. Suatu sistem pakar disusun oleh tiga modul yaitu :

a. Modul Penerimaan Pengetahuan (Knowledge Acquisition Mode)

Sistem berada pada modul ini pada saat user menerima pengetahuan dari pakar. Proses mengumpulkan pengetahuanpengetahuan yang akan digunakan untuk pengembangan sistem dilakukan dengan bantuan knowledge engineer. Proses knowledge engineer adalah sebagai penghubung antara suatu sistem pakar dengan pakarnya.

b. Modul Konsultasi (Consultation Mode) Pada saat sistem berada pada posisi memberikan jawaban atas permasalahan yang diajukan oeh user. Sistem pakar berada dalam modul konsultasi. Pada modul ini user berinteraksi dengan sistem dengan menjawab pertanyaan-pertanyaan yang diajukan oleh sistem.

c. Modul Penjelasan (Explanation Mode) Modul ini menjelaskan proses pengambilan keputusan oleh sistem (bagaimana suatu keputusan dapat diperoleh). 


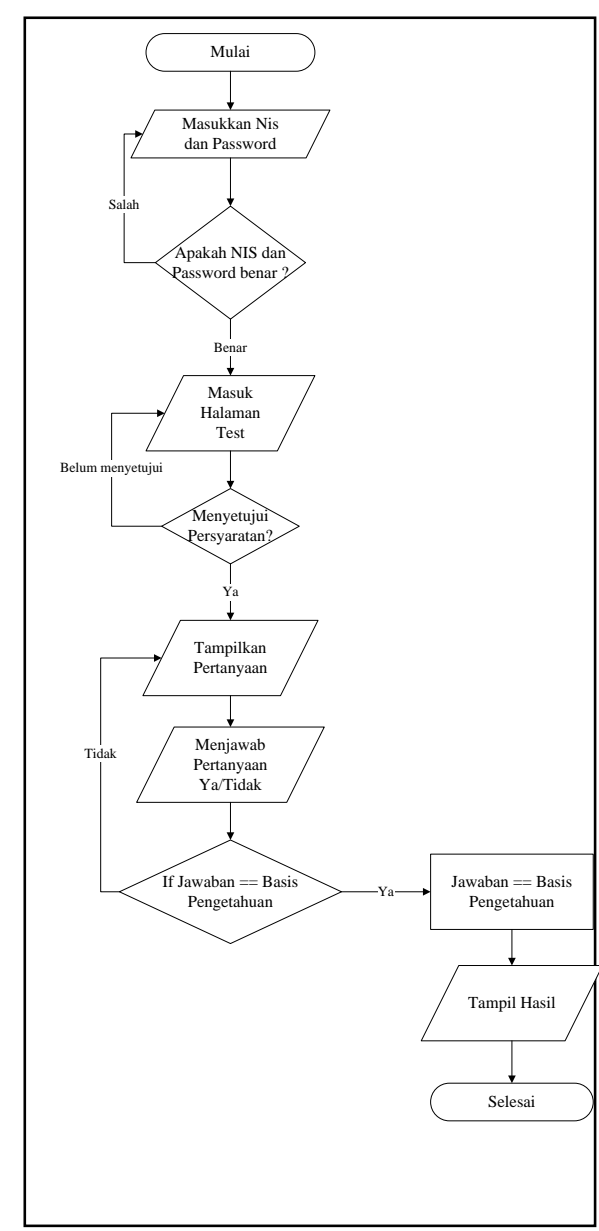

Sumber: Hasil penelitian (2016)

\section{Gambar 1. Rancangan Algoritma Forward Chaining}

\section{Basis Pengetahuan}

Arhami (2005:15) Isi dari basis pengetahuan adalah fakta-fakta dan atuaranaturan yang dipakai oleh beberapa pakar dengan dilandasi pengetahuan yang diperoleh dari pengalaman beberapa pakar. Untuk mempresentasikan pengetahuan digunakan metode kaidah produksi yang biasanya ditulis dalam bentuk Jika-Maka (If-Then).

\section{Rule - Rule pada Pakar}

Rule $1:$ IF Memperbaiki alat - alat elektronik And Memperbaiki Mobil And Memperbaiki alat - alat mekanik And Membuat sesuatu dengan kayu And Mengambil kursus Pendidikan Teknologi (misalnya seni industri, toko) And Mengambil kursus menggambar Mekanik And Mengambil kursus Perkayuan
And Mengambil kursus mekanika mobil/motor And Bekerja dengan seorang ahli mekanik atau teknisi And Bekerja diluar ruangan And Mengoperasikan mesin - mesin atau peralatan bermotor And Pernah menggunakan perkakas perkayuan berat, seperti gergaji besar, mesin bubut, atau penabur pasir And membuat gambar berskala And mengganti oli atau ban mobil And pernah mengoprasikan perkakas berat seperti bor tekan, gerinda, atau mesin jahit And membuat furniture atau kerajinan kayu And memperbaiki peralatan elektrik And memperbaiki furniture And mengunakan perkakas-perkakas pertukangan And melakukan perbaikkan pipa ledeng sederhana And membuat bahan sederhana dari kayu And mengecat ruangan - ruangan dari suatu rumah atau apartement And Mekanik pesawat And Mekanik mobil And Tukang Kayu And Pengemudi truk And Peninjau (Surveyor) And Inspektur kontruksi And Mekanik radio And Mekanik lokomotif And Masinis And Ahli listrik And Petani And Pilot helikopter And Teknisi elektronika And Tukang las Then minat bakatnya adalah REALISTIC

Rule 2 : IF Membaca buku-buku atau majalah-majalah ilmiah And Bekerja di kantor atau laboratorium penelitian And Mengerjakan sebuah proyek ilmiah And Mempelajari teori ilmiah And Bekerja dengan bahan kimia And Menerapkan matematika dalam masalah-masalah praktis And Mengambil mata kuliah fisika And Mengambil mata kuliah kimia And Mengambil mata kuliah matematika And Mengambil mata kuliah Biologi And Mempelajari masalah-masalah ilmiah atau teknisi And menggunakan aljabar untuk memcahkan masalah -masalah matematika And Saya dapat melakukan eksperimen atau survei ilmiah And mengerti "half-life"(waktu paruh) dari elemen sebuah radio aktif And menggunakan tabel-tabel logaritma And menggunakan komputer untuk mempelajari suatu masalah And menggambarkan fungsi dari sel-sel darah putih And menginterpretasikan rumus sederhana kimia And mengapa orang mebuat satelit tidak jauh dari bumi And menulis sebuah laporan ilmiah And mengerti akan teori "Ledakan Besar" (Big Bang) dari alam semesta And mengerti akan peranan DNA dalam genetika And Ahli Cuaca And Ahli biologi And Ahli perbintangan And Teknisi laboratorium kesehatan And Antropologi And Apoteker And Ilmuan Penelitian Independen And 
Penulis artikel ilmu ilmiah And Ahli Geologi And Ahli tumbuh-tumbuhan And Pekerjaan penelitian Ilmiah And Ahli Fisika And Peneliti ilmu social And Analisis lingkungan Then minat bakatnya adalah INVESTIGATIVE

Rule 3: IF Membuat sketsa, menggambar, atau melukis And Medesain furniture, pakaian, atau poster And Bermain dalam band, kelompok musik, atau orkestra And Latihan Instrumen Musik And Membuat potret - potret atau fotografi And Menulis novel atau bermain drama And Mengambil mata kuliah seni And Mengarahkan atau mengkomposisikan segala jenis musik And Bekerja dengan seorang seniman, penulis, atau pengukir yang berbakat And Mempertunjukkan untuk orang lain (menari, seni, dan lainnya) And Membaca artikel tentang seni, sastra, atau musik And dapat memainkan sebuah intrumen musikal And berpartisipasi dalam dua atau empat bagian nyanyian paduan suara And berperan sebagai pemusik solo And berakting dalam sebuah pertunjukkan And melakukan pemahaman bacaan And mengerjakan suatu lukisan, pewarnaan, atau ukiran $\boldsymbol{A n d}$ mengarahkan atau mengkomposisikan musik And mendesain pakaian, poster, atau furniture And menulis cerita atau puisi dengan baik And menulis sebuah pidato And membuat foto yang menarik And Penyair And Musisi And Novelis And Aktor/Aktris And Penulis lepas And Pengarah music And Jurnalis And Seniman And Penyanyi And Komposer And Pemahat And Dermawan And Kartunis And Penghibur Then minat bakatnya adalah ARTISTIC

Rule 4: IF Bertemu dengan tokoh pendidik atau terapis yang penting And Membaca artikel atau buku sosiologi And Bekerja untuk yayasan amal And Membantu orang lain dengan masalah - masalah pribadi mereka And Mempelajari perilaku kriminal anak muda And Membaca artikel atau buku psikologi And Mengambil mata kuliah HUMAS (Hubungan Masyarakat) And Mengajar di Sekolah Menengah Umum And Mengawasi kegiatankegiatan untuk pasien rumah sakit jiwa And Mengajar orang-orang dewasa And Bekerja sebagai sukarelawan And dapat dengan mudah berbicara dengan berbagai macam orang And mahir dalam menjelaskan kepada orang lain And dapat bekerja sebagai pengorganisasian lingkungan (RT) And Orang-orang mencari saya untuk mengutarakan masalah mereka And mengajari anak- anak dengan mudah And mengajari orang-orang dewasa dengan mudah And mahir dalam membantu orang-orang yang sedih atau bermasalah And mempunyai pemahaman yang baik akan hubunganhubungan sosial And mahir dalam mengajari orang lain And membuat orang orang merasa nyaman And lebih baik bekerja dengan orangorang dibandingkan dengan alat-alat atau ideide And Konsultan karir And Ahli kemasyarakatan And Guru SMU And Penasehat penyalahgunaan zat-zat berbahaya And Ahli kejahan anak-anak muda And dapat mengajari orang -orang dewasa dengan mudah And Konsultan pernikahan And Psikolog klinik And Guru ilmu sosial And Konsultan pribadi And Kepala kemah anak muda And Pekerjaan social And Penasehat rehabilitasi And Kepala tempat bermain Then minat bakatnya adalah SOCIAL

Rule 5: IF Mempelajari strategi-strategi untuk keberhasilan bisnis And Menjalankan bisnis-bisnis atau jasa milik sendiri And Menghadiri konfrensi penjualan And Mengambil semester pendek tentang administrasi atau kepemimpinan And Menjalani sebagai seorang petugas pada beberapa kelompok And Melakukan supervisi pekerjaan orang lain And Bertemu eksekutifeksekutif atau pimpinan penting And Memimpin suatu kelompok dalam memilih beberapa tujuan And Berpatisipasi dalam suatu kampanye politik And Bertindak sebagai seorang konsultan organisasi atau bisnis And Membaca majalah-majalah atau artikel-artikel And Tahu bagaimana cara menjadi pemimpin yang sangat sukses And Pembicara yang baik And mengelola sebuah kampanye penjualan And dapat mengorganisir pekerjaan orang - orang lain And seorang yang ambisius dan tegas And mahir dalam mendapatkan orang-orang untuk melakukan hal-hal dengan cara saya And penjual yang baik And pendebat yang baik And seorang yang sangat persuasif (sangat mempengaruhi) And mempunyai keahlian perencanaan And mempunyai beberapa keahlian kepemimpinan And Pembeli And Eksekutif periklanan And Perwakilan And Business Executive And Pebawa Acara (MC) And Tenaga Penjual And Tenaga penjual real estate And Manager departement store And Manajer penjualan And Eksekutif humas And Manajer stasiun televisi And Pemilik bisnis kecil And Pembuat undang-undang And Manager bandara Then minat bakatnya adalah ENTERPRENEURSHIP 
Rule 6: IF Mengisi formulir pajak penghasilan And Menambah, mengurangi, megkalikan, dan membagi angka-angka dalam bisnis atau tata buku And Mengoperasikan mesin-mesin kantor And Membiasakan pencatatan pengeluaran dengan detail And Menyiapkan suatu sistem pencatatan And Mengambil matakuliah akuntansi And Mengambil mata kuliah matematika perniagaan And Menangani suatu persediaan perlengkapan atau produk And Memeriksa kesalahan kertas kerja atau kecatatan produk And Mempengaruhi pencatatan atau file And Bekerja di kantor And mengarsipkan korespondeni dan kertas -kertas lain And Saya dapat melakukan sebuah pekerjaan kantor And Saya dapat melakukan mesin pembukuan otomatis And Saya akan melakukan banyak pekerjaan administrasi dalam waktu singkat And menggunakan peralatan sederhana untuk memproes data And membukukan pengeluaan dan pemasukkan And melakukan pencatatan akurat atas pembayaran atau penjualan And memasukkan informasi pada komputer And menulis surat-surat bisnis And melakukan beberapa kegiatan rutin kantor And seorang yang hati-hati dan teratur And Tenaga pembukuan And Peninjau kembali anggaran And Akutan publik tersertifikasi And Penyelidik kredit And Teller bank And Ahli pajak And Pengontrol inventaris And Operator komputer And Analisis keuangan And Cost Controller And Kasir yang membayar gaji And Pemeriksa bank And Kasir keuangan And Kasir audit Then minat bakatnya adalah CONVENTIONAL

\section{Pohon Pakar}

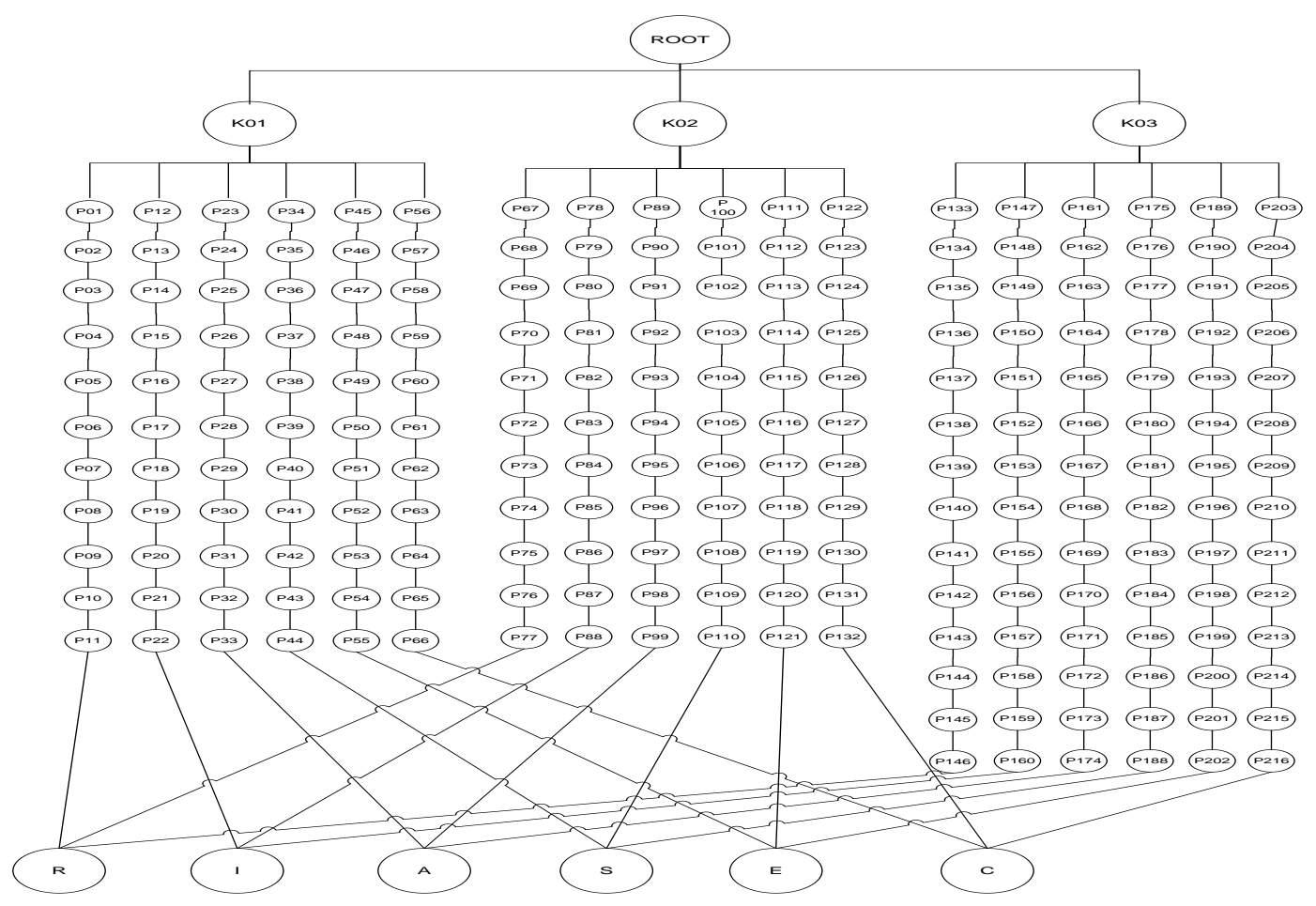

Sumber: Hasil penelitian (2016)

Gambar 2. Pohon Pakar 
PARADIGMA Vol. XVIII. No.2 September 2016

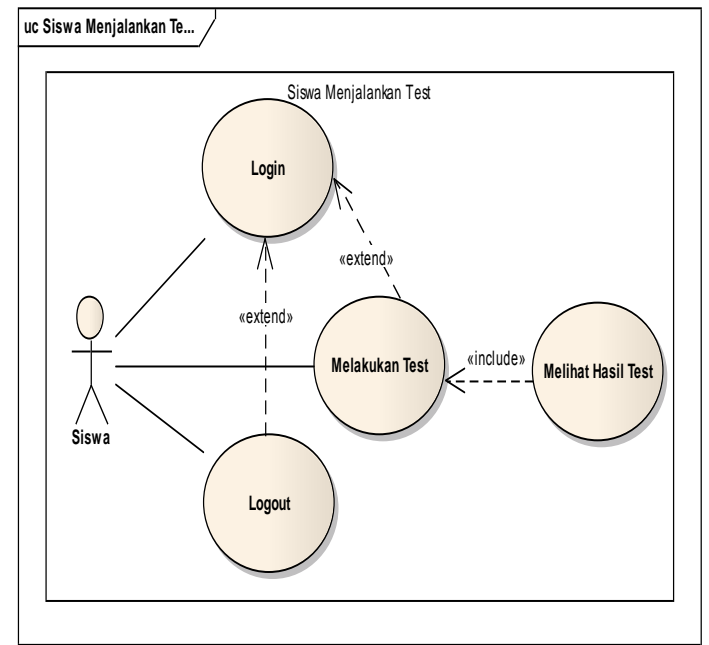

Sumber: Hasil penelitian (2016)

Gambar 3. Usecase Diagram Siswa Menjalakan Test

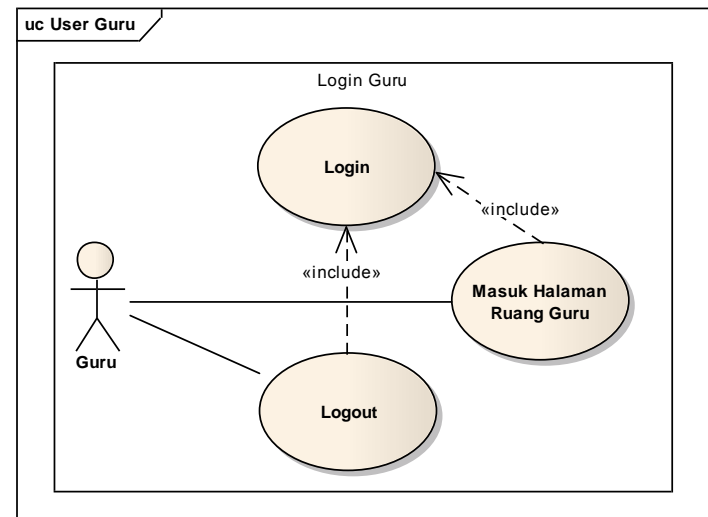

Sumber: Hasil penelitian (2016)

Gambar 4. Use Case Diagram Login Guru

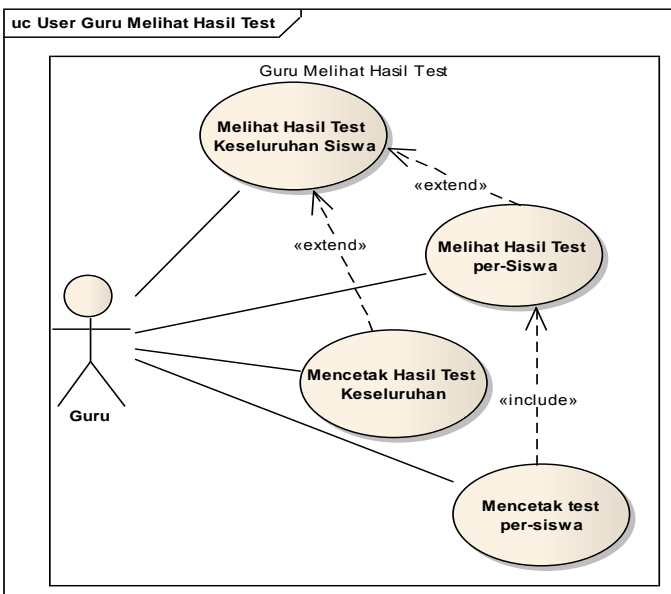

Sumber: Hasil penelitian (2016)

Gambar 5. Use Case Diagram Guru Melihat Hasil Test Siswa

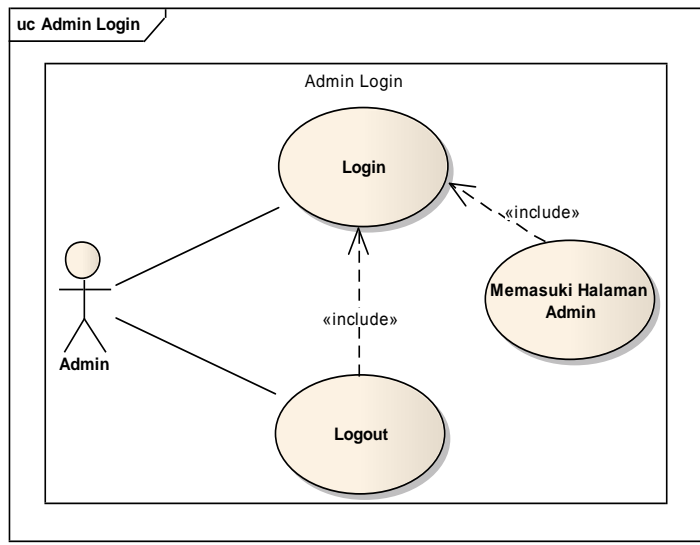

Sumber: Hasil penelitian (2016)

Gambar 6. Use Case Diagram Admin Login

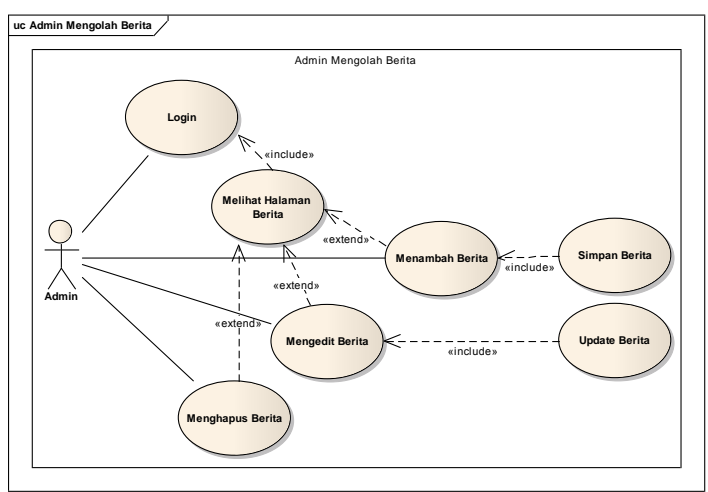

Sumber: Hasil penelitian (2016)

Gambar 7. Use Case Diagram Admin Mengolah Berita

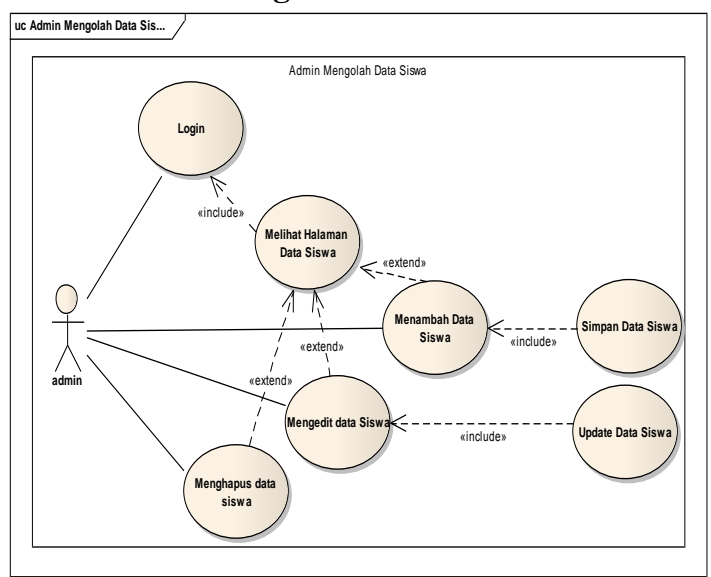

Sumber: Hasil penelitian (2016)

Gambar 8. Use Case Diagram Admin Mengolah Data Siswa 
PARADIGMA Vol. XVIII. No.2 September 2016

\section{E. ERD}

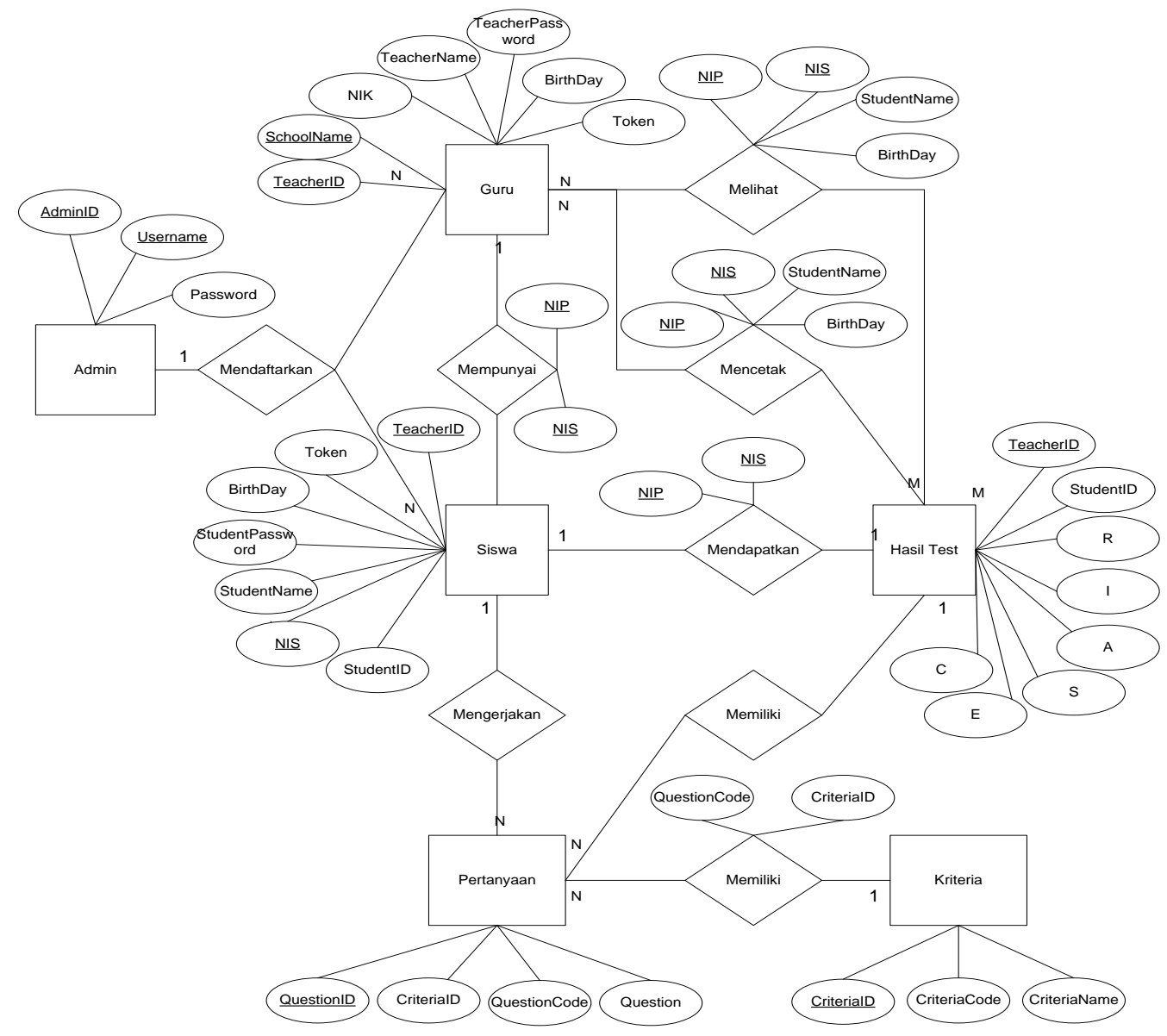

Sumber: Hasil penelitian (2016)

Gambar 9. ERD Diagram 


\section{F. Activity Diagram}

A. Siswa melakukan Test

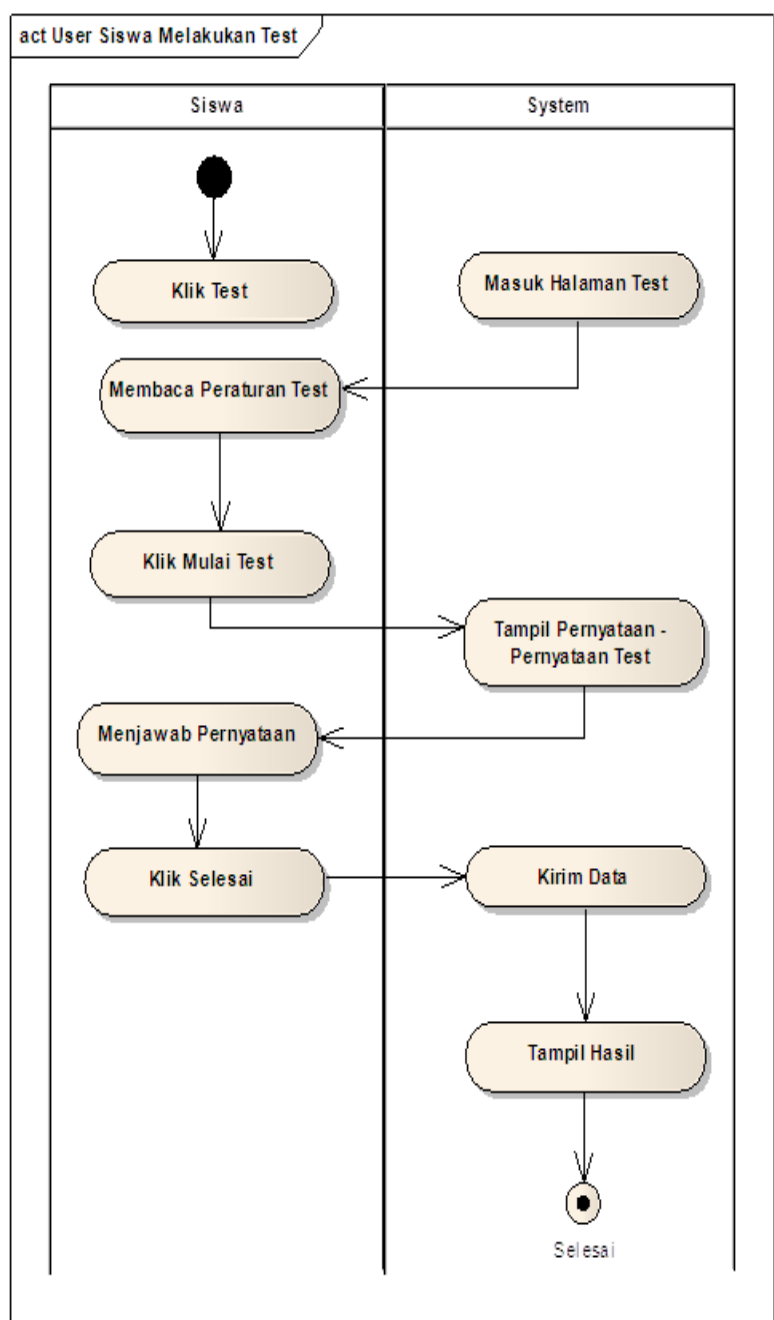

Sumber: Hasil penelitian (2016)

Gambar 9. ActiviydiagramSiswa melakukan Tes

\section{B. Login Guru}

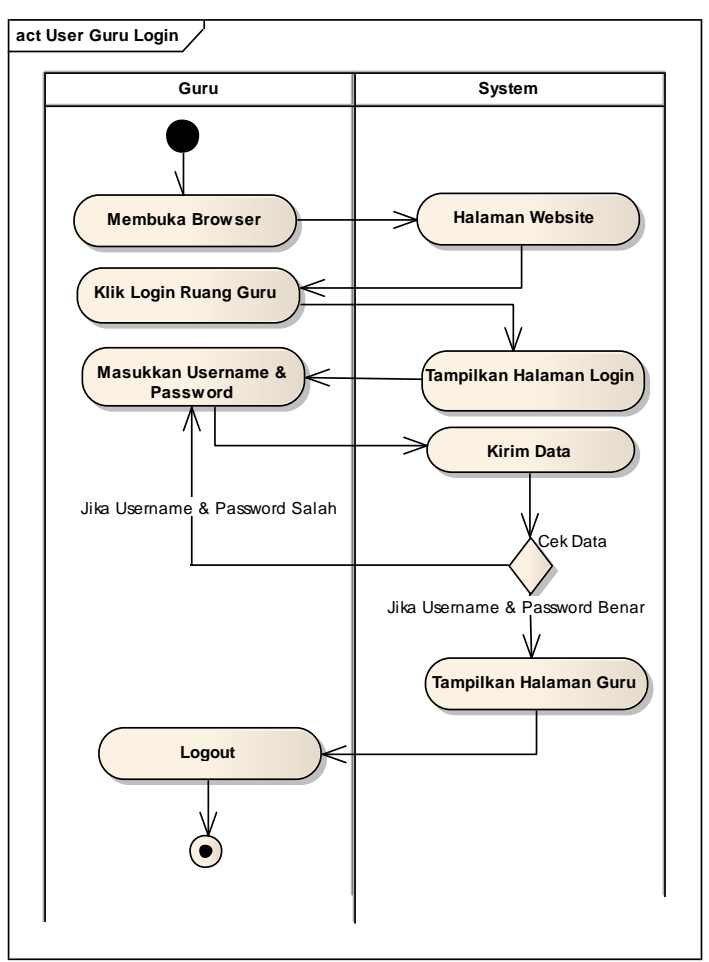

Sumber: Hasil penelitian (2016)

Gambar 10. Activity Diagram Guru Login

C. Cetak Hasil Keseluruhan

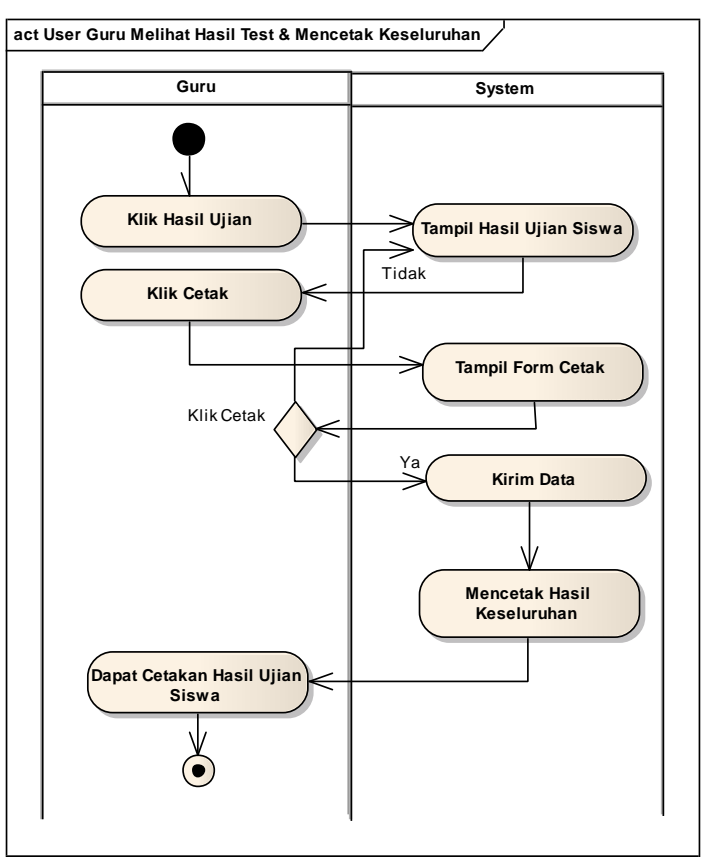

Sumber: Hasil penelitian (2016)

Gambar 11. Activity Diagram Melihat dan Mencetak Hasil Test Keseluruhan 


\section{Cetak Hasil Per Siswa}

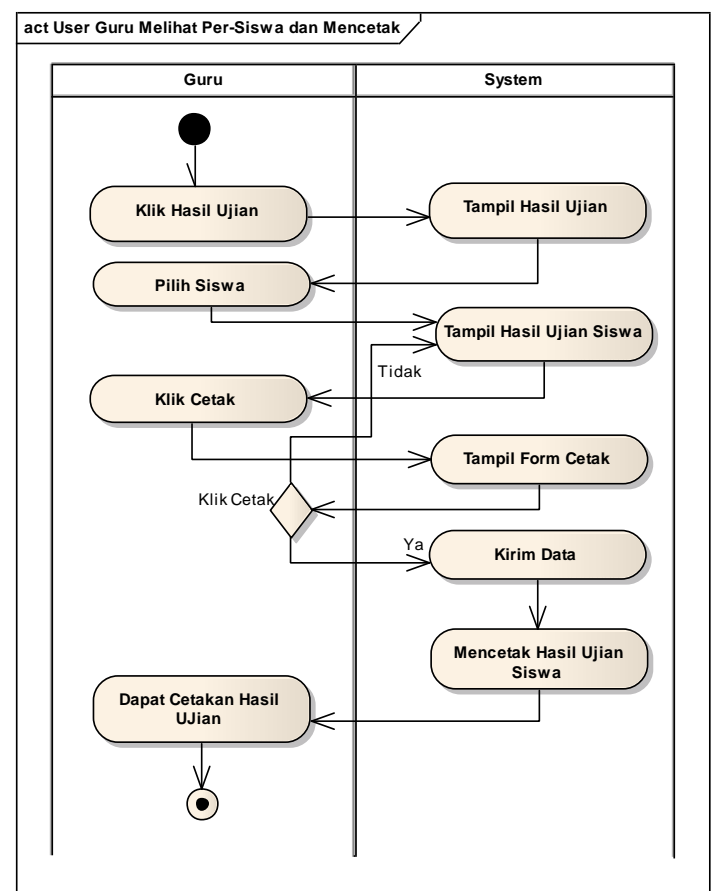

Sumber: Hasil penelitian (2016)

Gambar 12. Activity Diagram Guru Melihat dan Mencetak Hasil Test Per Siswa

\section{f. User Interface}

A. Halaman Login Siswa

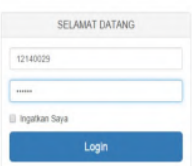

Sumber: Hasil penelitian (2016)

Gambar 13. Login Siswa

B. Halaman Ruang Siswa

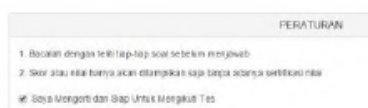

Sumber: Hasil penelitian (2016)

Gambar 14. Ruang Siswa
C. Halaman soal - soal yang harus dijawab oleh siswa.

Sumber: Hasil penelitian (2016)

Gambar 15. Soal-Soal

D. Hasil test setelah siswa menjawab semua pertanyaan yang diberikan.

Sumber: Hasil penelitian (2016)

Gambar 16. Hasil Test Setelah Siswa Menjawab

E. Halaman Hasil test keseluruhan dari siswa yang mengikuti test di satu sekolah.

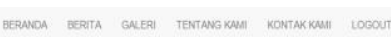

Nilai Siswa

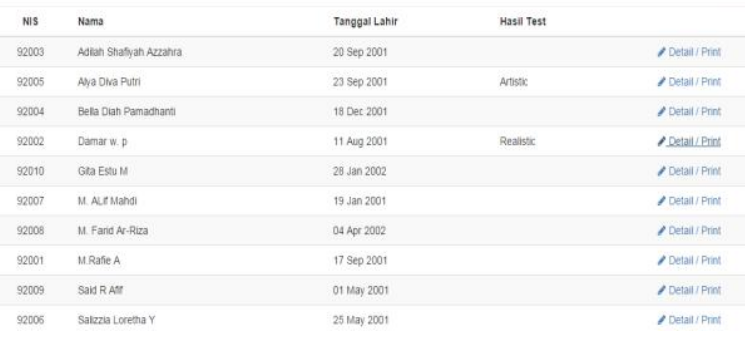

Sumber: Hasil penelitian (2016)

Gambar 17. Hasil Test Keseluruhan 


\section{F. Halaman hasil test Per Siswa}

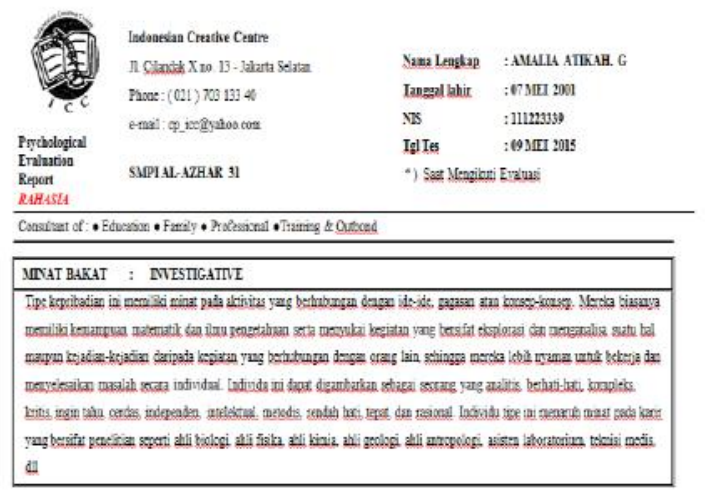

Sumber: Hasil penelitian (2016)

Gambar 18. Hasil Test Per Siswa

\section{PENUTUP}

Berdasarkan hasil penelitian dan pembahasan serta pengolahan hasil wawancara yang telah dilakukan, dan data-data yang yang menjadi dasar penelitian maka didapatkan beberapa kesimpulan diantaranya sebagai berikut:

1. Sistem pakar ini dapat menganalisa minat bakat dengan melihat jawaban-jawaban yang diberikan peserta tes dari pertanyaanpertanyaan yang ada pada sistem.

2. Dengan adanya aplikasi sistem pakar yang berbasis web ini dapat memudahkan dan membantu pelaksana pemeriksa tugas untuk menganalisa minat bakat dari peserta yang banyak secara online dan singkat serta mempermudah guru bimbingan konseling melihat hasil minat bakat siswanya agar dapat memberikan pengarahan pengembangan bakat dari siswanya tersebut sesuai minat bakatnya

3. Aplikasi sistem pakar ini berguna untuk membantu pengguna dalam menganalisa minat bakat dengan cara melakukan input jawaban dari pernyataan yang telah ada pada sistem pakar ini di setiap aspek dari hasil inputan data-data kondisi pernyataan dengan jawabannya nya, maka di dapatkan hasil analisa dari minat bakat lengkap dengan analisa profesi yang seharusnya difokuskan sesuai minat bakatnya.

4. Sistem yang dibangun penulis pada intinya hanya sebatas menganalisa minat bakat saja, diharapkan jika akan dikembangkan sistem pakar ini juga dapat menganalisa pada penjurusan Sekolah Menengah Atas (IPA/IPS).

5. Pengetahuan tentang minat bakat yang dikembangankan saat ini adalah analisa sistem minat bakat yang dilandasi dari pertanyaan-pertanyaan suatu kemampuan utama, dari hasil penelitian ada beberapa aspek yang dapat mempengaruhi minat bakat, yaitu lingkungan dan kegiatan sehari-hari. Dengan adanya penambahan itu memungkinkan sistem pakar ini akan dapat menganalisa suatu minat bakat yang lebih detail dan dapat menampilkan informasi yang lebih luas.

6. Diharapkan ada pengembangan lainnya di aplikasi sistem pakar ini seperti, tes intelligence quotient (IQ), tes taraf kecerdasan, tes kemampuan verbal, tes kempuan berfikir logis, dan tes evaluasi psikologis lainnya secara lengkap.

\section{DAFTAR PUSTAKA}

Andyati, Dina. 2012. Sistem Pakar Dalam Bidang Psikologi. ISSN: 1979-911X. Yogyakarta:Jurnal Ilmiah Prosiding Seminar Nasional Aplikasi Sains \& Teknologi (SNAST) Periode III November 2009 B287-B293.

Arhami, Muhammad. 2005. Konsep Dasar Sistem Pakar. Yogyakarta: Andi.

A.S, Rosa dan M. Shalahuddin. 2013. Rekayasa Perangkat Lunak (Terstruktur dan Berorientasi Objek). Bandung: Informatika.

Kusrini. 2006. Sistem Pakar Teori dan Aplikasi. Yogyakarta: Andi Offset.

Ladjamudin, Al-Bahra bin. 2006. Rekayasa Perangkat Lunak. Yogyakarta: Graha Ilmu.

Nugroho, Adi, George John Leopald Nikijuluw, Theresia Herlina Rochadiani, dan Ike Kurniawati Wijaya (Penterjemah). 2012. Rekayasa Perangkat Lunak - Buku Satu Pendekatan Praktisi (Edisi 7). Yogyakarta: Andi.

Perbawa, Doddy Satria, Wawan Laksito dan Didik Nugroho. 2010. Sistem Pakar Perilaku Buruk Psikologi pada Anak dengan Metode Forward Chaining. 
PARADIGMA Vol. XVIII. No.2 September 2016

ISSN : 1963 - 1173. Jakarta : Jurnal Ilmiah Sinus.

Prasetyo, Dwi Sunar. 2008. Bimbingan dan Pelatihan Tes IQ dan Kepribadian Anda. Yogyakarta: Diva Press.

Sukmoko, Didik Adi. 2006. Tes Kepribadian Minat dan Bakat. Yogyakarta: Agromrdia Pustaka.

Suteja, Benard R. 2006. Membuat Aplikasi Web Interaktif dengan ASP. Bandung: Informatika Bandung.
Tarigan, Feriani Astuti. 2013. Sistem Pakar Untuk Penyusunan Jadwal Kuliah Berbasis Forward Chaining. ISSN : 2337 - 3601. Medan: Jurnal TIME, Vol. II No.2.

Winarno, Edy, Ali Zaki, dan SmitDev Community. 2014. ASP.NET untuk Pemula. Jakarta: PT.Elex Media Komputindo 